\title{
The impact of changes in the timing of precipitation on the herbaceous understorey of Mediterranean evergreen oak woodlands
}

\author{
Marjan Jongen $^{\mathrm{a}, *}$, Xavier Lecomte ${ }^{\mathrm{a}}$, Stephan Unger ${ }^{\mathrm{a}}$, Marta Pintó-Marijuan ${ }^{\mathrm{b}}$, João Santos Pereira ${ }^{\mathrm{a}}$ \\ a Instituto Superior de Agronomia, Universidade Técnica de Lisboa, Tapada da Ajuda, 1349-017 Lisboa, Portugal \\ ${ }^{\mathrm{b}}$ Instituto de Tecnologia Química e Biológica, Universidade Nova de Lisboa, 2781-901 Oeiras, Portugal
}

\section{A R T I C L E I N F O}

\section{Article history:}

Received 9 October 2012

Received in revised form

23 November 2012

Accepted 27 November 2012

\section{Keywords:}

Climate change

Herbaceous understorey

Mediterranean ecosystem

Primary productivity

Precipitation variability

Species composition

Vegetation gas exchange

\begin{abstract}
A B S T R A C T
Climate change scenarios for the Iberian Peninsula predict increasing temperatures and increasingly variable precipitation regimes, which will challenge the sustainability and biodiversity of Mediterranean ecosystems such as the semi-natural evergreen oak woodlands.

To assess the effects of precipitation variability on productivity, species composition and vegetation gas exchange of the understorey vegetation in a typical managed cork oak woodland, a large-scale rainfall manipulation experiment was established. We studied the impacts of a change in the timing of precipitation events on this ecosystem, without altering total annual precipitation inputs. The two water manipulation treatments were: 'weekly watering treatment', where natural conditions were simulated with a normal dry period of 7 days, and '3-weekly watering treatment', with the normal dry period increased three-fold to 21 days.

Our experimental precipitation patterns resulted in significant differences in temporal soil moisture dynamics between the two treatments. Average soil water content (SWC) at $3 \mathrm{~cm}$ depth during the growing season was $16.1 \pm 0.17 \%$ and $15.8 \pm 0.18 \%$ in the weekly and 3 -weekly watering treatments, respectively, with a mere 5\% increase in the variability of SWC when extending the dry period from one to three weeks. Water infiltration into deeper soil layers $(>50 \mathrm{~cm})$ was significantly higher in the 3-weekly watering treatment as compared to the weekly watering treatment. This might be beneficial to Quercus suber, the tree component in this ecosystem, as its extensive tree root system enables water acquisition from deeper soil layers.

However, manipulation of the within-season precipitation variability, with a shift to fewer, but larger rain events, without change in total precipitation amount, had no significant effect on aboveground net primary productivity (ANPP), belowground net primary productivity (BNPP) and species composition, with average values of peak biomass of $385 \mathrm{~g} \mathrm{~m}^{-2}$ and $222 \mathrm{~g} \mathrm{~m}^{-2}$ for ANPP and BNPP, respectively.

The experimental precipitation patterns did not result in significant differences in the vegetation gas exchange between the two watering treatments. The $\mathrm{CO}_{2}$ and $\mathrm{H}_{2} \mathrm{O}$ exchange parameters correlated well with air temperature. In addition, evapotranspiration showed a good correlation with SWC.

Incorporating the data of SWC in the conceptual 'bucket model' showed that, independently of the watering regime, soil water availability during the life-cycle of these annual plants did not reach severe water stress conditions, which can explain the lack of a significant treatment effect in our study. In addition, our results showed that the annual plant community in these Mediterranean ecosystems is well adapted to short-term drought, through their phenological patterns and physiological adaptations.
\end{abstract} (c) 2012 Elsevier B.V. All rights reserved.

\section{Introduction}

In the Iberian Peninsula, the evergreen oak woodlands - montados in Portugal and dehesas in Spain - are of great ecological

\footnotetext{
* Corresponding author at: Departamento de Ambiente, Território e Recursos Naturais, Instituto Superior de Agronomia, Universidade Técnica de Lisboa, Tapada da Ajuda, 1349-017 Lisboa, Portugal. Tel.: +351 21365 3515; fax: +351 213655000.

E-mail address: marjanjongen@isa.utl.pt (M. Jongen).
}

and socio-economic importance. In Portugal, montados represent $23 \%$ of the Portuguese forests (736,700 ha), and are considered a national heritage, key to biodiversity conservation and ecosystem services (Bugalho et al., 2011). Dominated by evergreen Quercus species, these savanna-type woodlands represent a multifunctional agro-silvo-pastoral system with woodlands, high quality pastures and agricultural cultivation areas coexistent in the same spatial range. The herbaceous layer, dominated by a diverse community of C3 annual species, plays a significant role for ecosystem productivity (Aires et al., 2008; Jongen et al., 2011; Pereira et al., 2007; 
Unger et al., 2009, 2010), and exerts a large influence on soil nutrient cycling and the ecosystem water balance (Moreno Marcos et al., 2007; Otieno et al., 2011). Species composition and productivity of the herbaceous layer show inter-annual fluctuations, due to variations in quantity and distribution of precipitation, and changes in temperature (Fiiueroa and Davy, 1991), which may become more pronounced in the future as Mediterranean ecosystems are expected to experience an increase in the severity of environmental stresses with ongoing climate change (Miranda et al., 2006).

Future scenarios for the Iberian Peninsula predict an increase in the mean air temperature of $2-4.5^{\circ} \mathrm{C}$ by the end of the 21 st century (IPCC, 2007), accompanied by a major increase in the frequency and intensity of heat waves (Miranda et al., 2006), and a change in precipitation by as much as $-20 \%$ in summer and $+10 \%$ in winter (IPCC, 2007).

The precipitation regime in Portugal is characterized by high irregularity in both spatial and temporal dimensions (de Lima et al., 2002; Trigo and DaCamara, 2000), and studies report an increasingly marked seasonality of the precipitation regime in the last century. Paredes et al. (2006) reported that since the early 1960s, precipitation in March in the central and western regions of the Iberian Peninsula has declined by about 50\%. Similarly, the Palmer drought severity index (PDSI) indicates an increase in the drought frequency in Portugal for the period of February to March (Pires, 2003). Analysing changes in precipitation indices for the period of 1903-2003 over the Iberian Peninsula, Gallego et al. (2011) reported intensifying precipitation events and an increase in the maximum number of dry days between two precipitation events for the region in which our study site is located. These findings are in line with climate change scenarios that predict an increased temporal variability in precipitation regimes (Easterling et al., 2000; Luterbacher et al., 2006).

As precipitation is the key driver of ecosystem functioning in Mediterranean ecosystems, and moreover, as changes in terrestrial carbon storage can affect the pace of ongoing climatic change (Cox et al., 2000), it is important to assess the effects of precipitation variability on ecosystem processes, including productivity. Regarding food security, future agricultural practices need adaptation and mitigation strategies to ensure sustainability and productivity under a changing climate, while at the same time maintaining biodiversity. Hence, an advanced knowledge of the impact of changes in precipitation variability on ecosystem stability and sustainability as well as crop and forage production is needed.

Addressing these issues, Knapp et al. (2008) developed a conceptual 'bucket model' predicting the responses of terrestrial ecosystems to more extreme intra-annual precipitation patterns, characterized by larger precipitation events with concurrently longer dry intervals. In mesic ecosystems, the 'bucket model' predicts more frequent and higher water stress with increasing precipitation variability. The larger but fewer precipitation events would amplify the soil water fluctuations, leading to extended dry periods, thereby increasing the occurrence of soil water levels beyond the stress threshold for vegetation productivity (Knapp et al., 2008). Indeed, for mesic ecosystems, several studies have shown increased plant water stress in response to increasing precipitation variability, resulting in a concomitant reduction of primary productivity in grasslands (Fay et al., 2003, 2008; Harper et al., 2005; Heisler-White et al., 2009; Knapp et al., 2002). However, in arid ecosystems seasonal water stress may even decrease with increasing precipitation variability, as the amplification of soil water dynamics would result in deeper soil water infiltration, thereby permitting soil moisture to be maintained above drought stress thresholds for longer periods (Knapp et al., 2008). Indeed, Thomey et al. (2011) found a reduction in soil moisture deficit, with a concomitant increase in aboveground net primary productivity (ANPP) in an arid grassland with increasing precipitation

variability. In semi-arid ecosystems, results to date are contrasting. In a semi-arid short grass steppe, Heisler-White et al. (2009) reported an increase in ANPP with more extreme rainfall patterns. However, Miranda et al. (2009) showed that in a semiarid grassland changes in precipitation frequency had no effect on ANPP, plant cover and diversity.

As information on the impacts of precipitation variability on Mediterranean grassland ecosystems is lacking, we established a large-scale rainfall manipulation experiment in a typical Mediterranean oak woodland, focusing on the herbaceous understorey vegetation. We simulated the predictions of altered rainfall regimes under future climate change scenarios by investigating the impacts of a change in the timing of precipitation events, without altering total annual precipitation inputs, on productivity, species composition and vegetation gas exchange. Our central hypothesis was that increasing precipitation variability would lead to more frequent water stress, thereby decreasing photosynthesis and ANPP of the herbaceous understorey.

\section{Material and methods}

\subsection{Site description}

The study was conducted at the Herdade da Machoqueira do Grou $\left(39^{\circ} 08^{\prime} 16^{\prime \prime} \mathrm{N}, 8^{\circ} 20^{\prime} 03^{\prime \prime} \mathrm{W}\right), 30 \mathrm{~km}$ northeast of Coruche, Portugal. The soil is a Cambisol (FAO), with $81 \%$ sand, $14 \%$ silt and $5 \%$ clay. Field capacity at a depth of $5 \mathrm{~cm}$, measured as the volumetric water content of the soil two days after a large irrigation event $(80 \mathrm{~mm})$, is $19.3 \%$ ( $\mathrm{SE}=0.44, n=16)$. Volumetric soil water content at the permanent wilting point, measured at $-1.5 \mathrm{MPa}$ using a pressure plate extractor is $7.6 \%(\mathrm{SE}=0.24, n=12)$. The climate is Mediterranean, characterized by wet and mild winters, and dry and hot summers. Long-term mean annual temperature is approximately $15.9^{\circ} \mathrm{C}$ and long-term mean annual precipitation is $680 \mathrm{~mm}$ (Inst. de Meteorologia, Lisbon). The study site is an evergreen oak woodland (montado) with Quercus suber being the only tree species. The tree cover is about $50 \%$, with a tree density of 177 trees per ha. Average tree height is $7.9 \mathrm{~m}$. The understorey vegetation consists of a mixture of C3 annual species (mainly forbs and grasses), emerging after the first rains in autumn and senescing in late spring. In May 2009, the dominant species of the understorey vegetation were Rumex acetosella, Tuberaria guttata, Tolpis barbata and Plantago coronopus, with grasses (Agrostis pourretii, Briza maxima, Vulpia bromoides and $V$. geniculata) comprising about $10 \%$ of the biomass. Aboveground productivity of the understorey vegetation in May 2009 was $64 \pm 7.7 \mathrm{~g} \mathrm{~m}^{-2}$. Until October 2009, the experimental site was intermittently grazed with a stocking density of 0.16 cattle ha $^{-1}$. In October 2009 , the site was ploughed and seeded with a mixture of legumes (Trifolium subterraneum T. michelianum-balansae, T. resupinatum, T. vesiculosum, T. incarnatum, T. glanduliferum, Biserrula pelecinum, Ornithopus sativus, 0 . compressus) and the grass Lolium multiflorum, this seed mixture (Charneca 650, S 07874) being supplied by Fertiprado, Vaiamonte, Portugal. Sowing legume-rich seed mixtures in agro-silvo-pastoral systems, such as the cork oak forests, is common agricultural practice in Portugal, to improve productivity and soil fertility (Crespo, 2010).

\subsection{Experimental design and rainfall manipulation}

In December 2009, eight rainfall manipulation shelters ('Fraga', Prilux, Ponte de Vagos, Portugal) were constructed within the 
fenced area, enabling manipulation of the precipitation received by the understorey. Each shelter covered an area of $6 \mathrm{~m} \times 5 \mathrm{~m}\left(30 \mathrm{~m}^{2}\right)$, with an eave height of $1.6 \mathrm{~m}$ and a ridge height of $2.5 \mathrm{~m}$. The shelters excluded natural rainfall from a $4 \mathrm{~m} \times 5 \mathrm{~m}$ core plot, used for measurements of plant and soil responses to altered rainfall regimes. The shelter roofs were covered in November 2010 by a clear, $2 \mathrm{~mm}$, UV-transparent polyethylene greenhouse film (Plásticos F. Matos, Massamá, Portugal). Shelter sides and ends were open in order to maximize air movement and minimize temperature and relative humidity artefacts. Each experimental plot was surrounded by a buried vertical perimeter barrier of galvanized sheet metal to a depth of $30 \mathrm{~cm}$, to minimize surface and subsoil water flow. Natural rainfall for application to the experimental plots was collected off the roof via gutters connected to plastic water storage tanks (1000 l, Agriloja, Portugal). The water manipulation treatment was based on historical precipitation data (1955-2007) for the experimental site (Inst. de Meteorologia, Lisbon). Average annual precipitation is $680 \pm 210 \mathrm{~mm}$, with $87 \%(594 \mathrm{~mm})$ of the precipitation being confined to the growing season (October 1 to May 31). Historical precipitation data give a median number of rain events during the growing season of 24 , with the median length of the dry periods being 7 days. The two water manipulation treatments were: 'weekly watering treatment', where natural conditions were simulated, and ' 3 -weekly watering treatment', with the normal dry period increased three-fold to 21 days. Each of the two manipulation treatments had four replicate experimental plots. To avoid a treatment effect on germination and seedling establishment, all experimental plots were subjected to equal water inputs until the end of November 2010, receiving $148 \mathrm{~mm}$ of water. From November 30 onwards, the weekly watering treatment received $16 \mathrm{~mm}$ of water every week and the 3-weekly watering treatment received $48 \mathrm{~mm}$ every three weeks. In total, precipitation inputs during the growing season of October 2010 to the end of May 2011 amounted to $590 \mathrm{~mm}$ for both treatments.

\subsection{Microclimate}

Air temperature and humidity were continuously measured using EHT sensors with radiation shields (Decagon Devices, Pullman, USA). Vapour pressure deficit (VPD) was calculated from the temperature and humidity data according to Goudriaan and van Laar (1994), and presented as the average values for the 11.00-18.00 h period. Photosynthetic photon flux density (PPFD) was continuously measured using a QSO-S PAR sensor (Decagon Devices, Pullman, USA). Volumetric soil water content (SWC) at a depth of $3 \mathrm{~cm}$ was measured continuously in each of the experimental plots using EC-5 soil moisture sensors (Decagon Devices, Pullman, USA). All above-mentioned sensors were connected to EM-50 data loggers (Decagon Devices, Pullman, USA), recording half-hourly means. Data on volumetric SWC at a depth of 10 , $20,30,40,60$ and $100 \mathrm{~cm}$ was obtained using soil profile probes (PR1, Delta-T Devices, Cambridge, UK), with measurements made $1 \mathrm{~h}$ before and $24 \mathrm{~h}$ after each 3-weekly watering event. PR1 data were used to estimate infiltration, calculated as the increase in the amount of water $\left(\mathrm{m} \mathrm{m}^{-2}\right)$ in each soil layer $24 \mathrm{~h}$ after watering as compared to pre-watering values. Precipitation was measured with a RG2 rain gauge (Delta-T Devices, Burwell, Cambridge, UK), and stored as half-hourly means on a DL2 data logger (Delta-T Devices, Burwell, Cambridge, UK).

\subsection{Primary productivity}

Germination of the herbaceous understorey in our montado ecosystem occurs in autumn after the first substantial precipitation event, with biomass development primarily confined to the period between February and May. Therefore aboveground net primary productivity (ANPP) was estimated on February 1, April 5, May 17 and June 6 , the latter date corresponding with the onset of senescence. All plant material in two $40 \mathrm{~cm} \times 40 \mathrm{~cm}$ quadrats within each experimental plot was harvested, and subsequently divided into live and senescent biomass, sorted into the individual species, oven dried at $60^{\circ} \mathrm{C}$ for $72 \mathrm{~h}$, and weighed to the nearest $0.001 \mathrm{~g}$.

Belowground net primary productivity (BNPP) was estimated at peak biomass (May 17). In each of the experimental plots two soil cores of $8 \mathrm{~cm}$ diameter and a depth of up to $20 \mathrm{~cm}$ were taken. Roots were washed out, scanned for root length and diameter, and analysed using WinRhizo software (Regents Instruments Inc., Canada), then oven dried at $60^{\circ} \mathrm{C}$ for $72 \mathrm{~h}$, and weighed.

On May 24, leaf area index (LAI) was measured using a ceptometer (AccuPAR model LP-80, Decagon Devices, Pullman, USA), allowing an indirect determination of LAI by measuring the fraction of intercepted photosynthetically active radiation (fiPAR) of a canopy.

\section{5. $\mathrm{CO}_{2}$ and water vapour fluxes}

Portable gas exchange chambers $(39.5 \mathrm{~cm} \times 39.5 \mathrm{~cm} \times 54 \mathrm{~cm})$ were used to estimate $\mathrm{CO}_{2}$ and water vapour fluxes of the herbaceous vegetation. Chambers constructed of transparent plexiglass (>95\% light transmittance) were used for measurements of net $\mathrm{CO}_{2}$ exchange flux $\left(F_{\mathrm{NET}}\right)$ and evapotranspiration (ET), and chambers constructed of opaque PVC, covered with an insulation layer of reflective aluminium foil, were used for measurements of the respiration flux $\left(F_{\mathrm{R}}\right)$. Measurements of $F_{\mathrm{NET}}, F_{\mathrm{R}}$ and ET were performed using the chamber in a closed system. To ensure optimal measurement conditions, chambers were well ventilated and tightly fitted on sampling frames inserted in the soil at least one week before measurements were conducted. After the chamber was fitted on the sampling frame, air was pumped through at $1000 \mathrm{ml} \mathrm{min}^{-1}$ passing a LI-840A infrared gas analyser (Li-Cor, Nebraska, USA) at the chamber outlet which recorded the change in chamber $\mathrm{CO}_{2}$ and $\mathrm{H}_{2} \mathrm{O}$ concentration over a time of $3 \mathrm{~min}$. Air temperature inside and outside the chambers was logged continuously during measurements, and temperature inside the chambers was maintained within $1^{\circ} \mathrm{C}$ relative to ambient temperature using ice packs. For a more detailed description of the chamber design and functioning, see $\mathrm{Li}$ et al. (2008). As the measurements of $F_{\mathrm{NET}}$ and $F_{\mathrm{R}}$ were closely associated in time, estimations of gross $\mathrm{CO}_{2}$ uptake $\left(F_{\mathrm{A}}\right)$ were made by subtraction of $F_{\mathrm{R}}$ from $F_{\mathrm{NET}}\left(F_{\mathrm{A}}=F_{\mathrm{R}}-F_{\mathrm{NET}}\right)$. Chamber measurements were partly organized around 3-weekly watering events (March 25 and April 1, and May 9 and 12), with additional measurements conducted immediately prior to weekly watering events (March 22, April 26 and May 3).

\subsection{Data analysis}

Statistical analysis was performed using Sigmaplot 11.0 (Systac Software, Inc., San Jose, USA) and the R statistical software package (R Development Core Team, 2010). Significance level was set to $p<0.05$. Data on LAI, BNPP and root to shoot ratio were analysed using a one-way ANOVA, with treatment being the only factor. Data on SWC, ANPP and vegetation gas exchange were analysed using a two-way repeated measures ANOVA, with treatment and date/time as factors. Data on infiltration and the relative abundance of functional groups, the latter arcsine transformed to ensure normality, were analysed using a three-way repeated measures ANOVA, with treatment, date and depth/functional group as factors. When a significant difference was found for a main factor, Fisher's LSD post hoc pairwise comparison was applied to determine individual differences between means. Linear regression analyses were used to relate gas exchange $\left(\mathrm{CO}_{2}\right.$ or $\left.\mathrm{H}_{2} \mathrm{O}\right)$ with temperature and soil water content. 


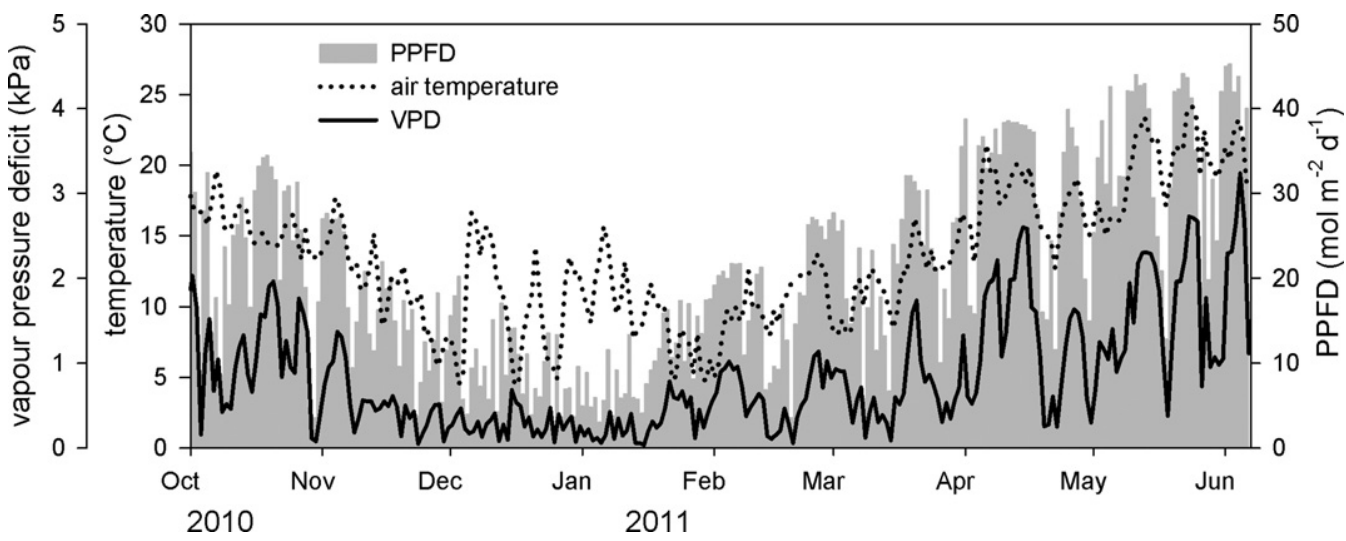

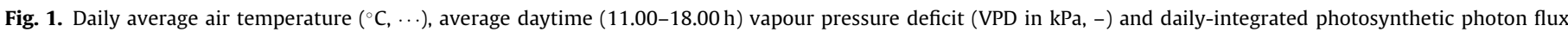
density (PPFD in $\mathrm{mol} \mathrm{m}^{-2} \mathrm{~d}^{-1},-$ ) at the experimental site over the course of the study.

\section{Results and discussion}

\subsection{Microclimate}

Daily average air temperature at the experimental site over the course of the study ranged from $4.5^{\circ} \mathrm{C}$ to $24.2{ }^{\circ} \mathrm{C}$ (Fig. 1), with daily-integrated PPFD varying between 2.7 and $45.2 \mathrm{~mol} \mathrm{~m}^{-2} \mathrm{~d}^{-1}$. December and January were relatively warm, with average daily temperature in the period of December 5 until January 20 exceeding $10^{\circ} \mathrm{C}$ on 31 occasions, with concomitant low VPD and PPFD. April 4 until 18 was characterized by a warm spell, with aboveaverage daily maximum temperatures of $27.6^{\circ} \mathrm{C}$, average VPD of $1.83 \mathrm{kPa}$ and high ( $>32 \mathrm{~mol} \mathrm{~m}^{-2} \mathrm{~d}^{-1}$ ) daily-integrated PPFD. From April 18 onwards the weather was variable; warm periods (May 11-15 and May 22-25) with VPD exceeding $2 \mathrm{kPa}$, occasionally alternated with cool periods. The high VPD in the warm periods might directly affect stomatal conductance, with partial stomatal closure limiting transpiration and photosynthesis.

More extreme precipitation patterns, without concurrent changes in total precipitation quantity, can have large effects on soil moisture dynamics (Fay et al., 2008; Knapp et al., 2002). Our experimental precipitation patterns (Fig. 2a) resulted in marked in temporal soil moisture dynamics between the two treatments (Fig. 2b). At the end of November, when the water manipulation treatment started, SWC was $15.4 \%$. Until the end of March, SWC remained above $14 \%$. However, from April onwards, higher temperatures in combination with increasing biomass and concomitant higher transpiration, resulted in a rapid decrease in SWC, with values as low as $7.4 \%$ and $8.0 \%$ in the weekly and 3-weekly watering treatments, respectively. Average SWC at $3 \mathrm{~cm}$ depth for the duration of water manipulation was $16.1 \pm 0.17 \%$ and $15.8 \pm 0.18 \%$ in the weekly and 3-weekly watering treatments, respectively. The variability of SWC, calculated as the CV of daily average SWC values, increased by a mere $5 \%$ (from 0.148 to 0.155 ) when extending the dry period from one to three weeks. This increase is very small, as compared to the $50 \%$ increase in the CV of SWC reported by Fay et al. (2008).

The temporal dynamics of the difference in soil moisture between the two treatments are shown in Fig. 2c. Soil moisture in the plots with water additions every 3 weeks was higher during 98 days, while the weekly watering treatment had higher soil moisture during 91 days. However, the integral of the difference in SWC in the weekly watering treatment was higher (181\% points as compared to $128 \%$ points), indicating a comparatively greater water availability. In general, the switch in SWC supremacy occurred at the 3-weekly watering event. However, on several occasions, this switch occurred several days before the 3-weekly watering event
(January 22, March 4 and 26), with SWC in the 3-weekly watering treatment exceeding that of the weekly watering treatment, even though these plots had not received any precipitation for more than two weeks.

Water infiltration through the soil profile, assessed $24 \mathrm{~h}$ after the watering events, was affected by the experimental precipitation patterns (Fig. 3). When watered, the 3 -weekly watering treatment received three times the amount of water, as compared to the weekly watering treatment. This resulted in significant differences in water infiltration into the deeper soil layers $(50-70 \mathrm{~cm}: p=0.006$, $70-100 \mathrm{~cm}: p=0.045)$. In the 3 -weekly watering treatment, soil moisture in the $70-100 \mathrm{~cm}$ deep soil layer increased by $1.91 \mathrm{~m}^{-2}$, as compared to a $0.21 \mathrm{~m}^{-2}$ increase in the weekly watering treatment. This difference was less pronounced in the $50-70 \mathrm{~cm}$ layer.

The montado ecosystem is characterized by the presence of an open tree layer, in our study site dominated by dispersed Q. suber, and an herbaceous understorey. These different plant functional types exploit niche partitioning, utilizing soil water in different soil layers (Joffre et al., 1999; Moreno et al., 2005; Moreno and Pulido, 2008).

In contrast to the herbaceous vegetation, the roots of which are confined to the top $20 \mathrm{~cm}$, the extensive tree root system of Q. suber enables water acquisition from deeper soil layers (Cubera and Moreno, 2007). Thus, the increase in soil moisture at depths $>50 \mathrm{~cm}$ in the 3-weekly watering treatment might be beneficial to Q. suber.

Cumulative infiltration, the total amount of water entering the soil profile $(0-100 \mathrm{~cm})$ within $24 \mathrm{~h}$ after the watering events, in the 3 -weekly watering treatment amounted to $25.21 \mathrm{~m}^{-2}$. These plots received $481 \mathrm{~m}^{-2}$ at each watering event, thus nearly half of the water applied did not contribute to the soil moisture increase. Possible explanations are surface run-off, subsurface lateral flow, or infiltration to soil layers $>100 \mathrm{~cm}$. In contrast, in the weekly watering treatment cumulative infiltration accounted for all the water applied.

\subsection{Primary productivity}

As low temperatures in winter deter plant growth in our ecosystem (Otieno et al., 2006), development of the herbaceous vegetation is primarily confined to the period between February and May. In February, aboveground net primary productivity (ANPP) was $111.2 \pm 7.6$ and $124.2 \pm 15.6 \mathrm{~g} \mathrm{~m}^{-2}$ in the weekly and 3-weekly watering treatments, respectively (Fig. 4). Over the growing season ANPP increased significantly $(p<0.001)$, reaching a peak in late spring, with values of $361.4 \pm 46.6$ and $409.0 \pm 70.4 \mathrm{~g} \mathrm{~m}^{-2}$ in the weekly and 3-weekly watering treatments, respectively. 

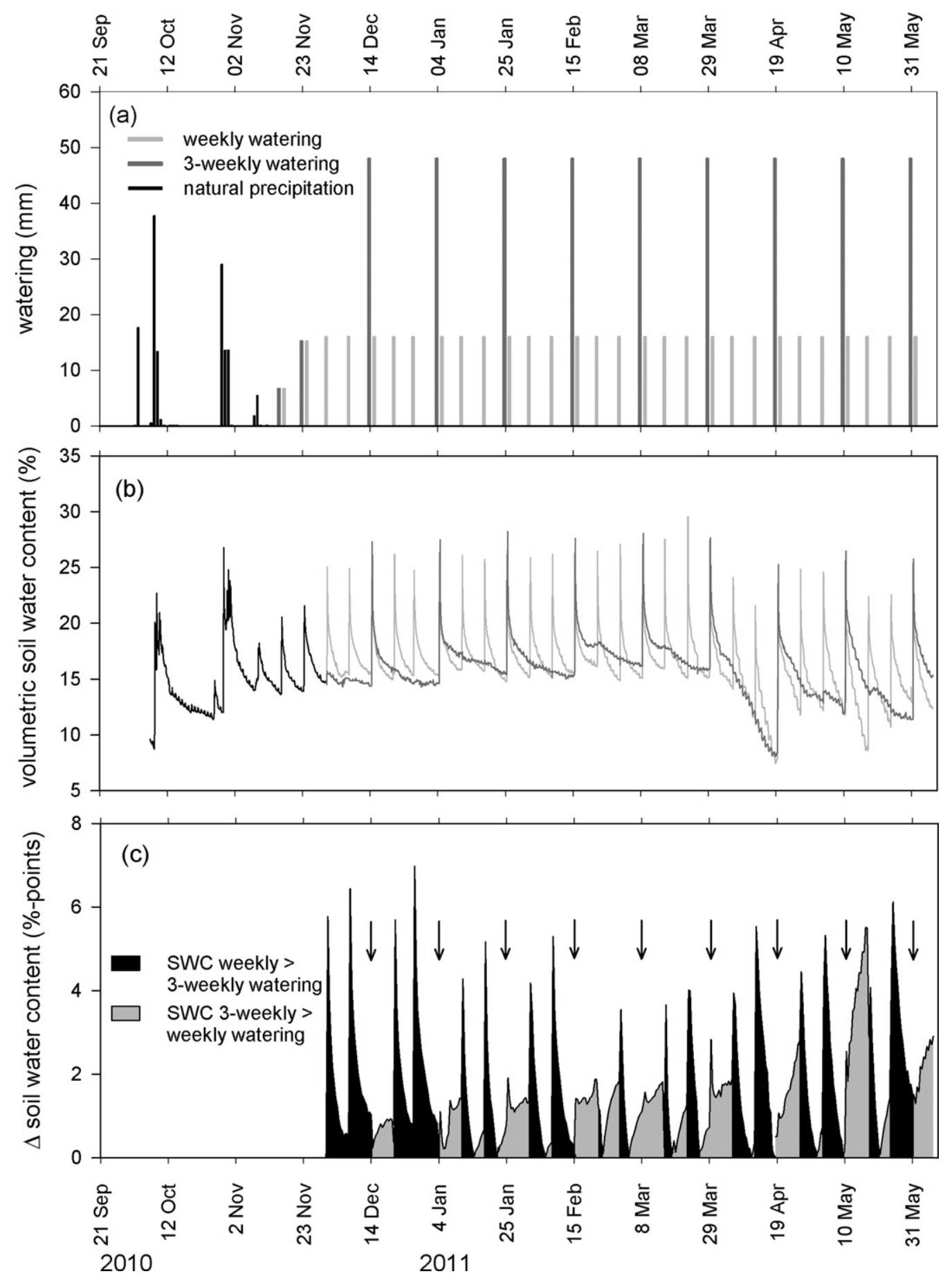

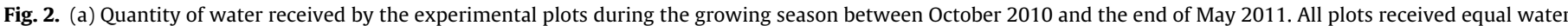

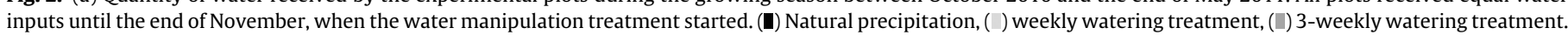

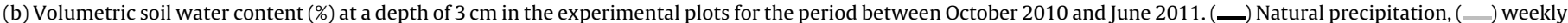

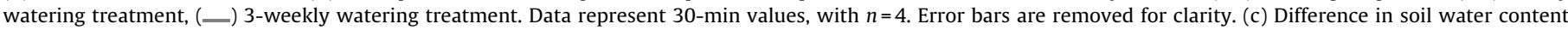

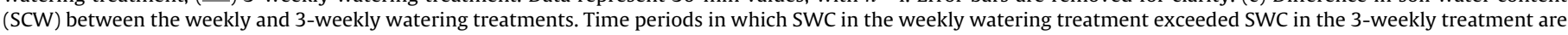

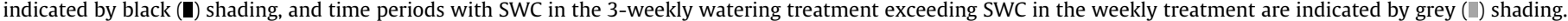
Timing of the 3-weekly watering is indicated by arrows.

Subsequently, the sward senesced due to increasing temperatures and decreasing soil water availability. Precipitation variability, with a shift to fewer, but larger rain events, had no effect on ANPP ( $p=0.74$, Fig. 4). Similarly, leaf area index (LAI) was not significantly affected $(p=0.20)$ by watering treatment (Table 1$)$, with an average value of $2.56 \mathrm{~m}^{2} \mathrm{~m}^{-2}$. Although the presence of inflorescences and maturing fruits may result in an overestimation of LAI, ANPP showed a good correlation with LAI $\left(r^{2}=0.85\right.$, $p<0.001$ ). Belowground net primary productivity (BNPP) and dry matter partitioning (calculated as the root to shoot ratio) were not affected by precipitation variability (BNPP: $p=0.69$; root to shoot ratio: $p=0.79$ ), with average values of $221.8 \pm 18.1 \mathrm{~g} \mathrm{~m}^{-2}$ 
Table 1

Leaf area index (LAI), belowground net primary productivity (BNPP), root to shoot ratio and specific root length (SRL) in the weekly and 3-weekly watering treatments. Measurements taken at peak biomass (end of May). Data represent mean $\pm \mathrm{SE}, n=4$. No significant differences (at $p<0.05$ ) were found between the two treatments.

\begin{tabular}{lcc}
\hline & $\begin{array}{l}\text { Weekly watering } \\
\text { treatment }\end{array}$ & $\begin{array}{l}\text { 3-Weekly watering } \\
\text { treatment }\end{array}$ \\
\hline LAI & $2.25 \pm 0.36$ & $2.87 \pm 0.39$ \\
BNPP $\left(\mathrm{g} \mathrm{m}^{-2}\right)$ & $213.8 \pm 18.3$ & $229.8 \pm 33.9$ \\
Root to shoot ratio & $0.589 \pm 0.049$ & $0.605 \pm 0.029$ \\
SRL $\left(\mathrm{m} \mathrm{g}^{-1}\right)$ & $101.8 \pm 10.0$ & $115.4 \pm 11.7$ \\
\hline
\end{tabular}

and $0.597 \pm 0.027$, respectively. In addition, specific root length, as indicator of the resource uptake potential, was not significantly different ( $p=0.41$ ) between the two watering treatments (Table 1 ).

Previous studies have reported peak aboveground biomass for the herbaceous vegetation in montado ecosystems in Portugal of $200 \mathrm{~g} \mathrm{~m}^{-2}$ (Castro and Freitas, 2009; Otieno et al., 2011). Aboveground biomass in a Spanish dehesa over a 20 -year period averaged 125 and $288 \mathrm{~g} \mathrm{~m}^{-2}$ in the upper and lower slope zones of these semi-arid grasslands (Vázquez-de-Aldana et al., 2008). The higher productivity in our study reflects the positive effects of management practice, with the site being ploughed and seeded in 2009.

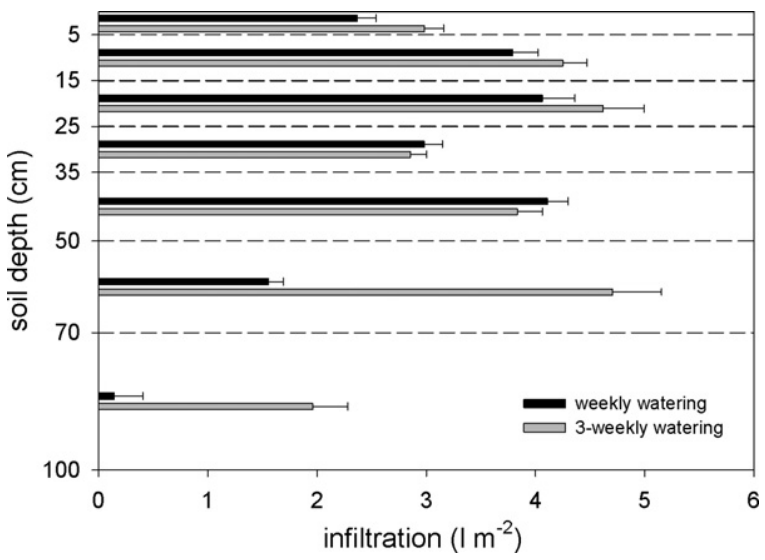

Fig. 3. Water infiltration through the soil profile. Data represents the increase in the amount of water in the respective soil layer $24 \mathrm{~h}$ after the watering events, with

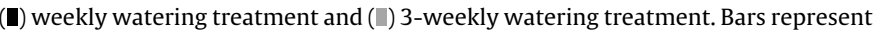
mean \pm SE, $n=36$.
ANPP in grassland ecosystems has been shown to correlate well with annual precipitation (Jongen et al., 2011; Knapp and Smith, 2001; Sala et al., 1988; Vázquez-de-Aldana et al., 2008; Yang et al., 2008), although net productivity in any given year can stray from this linear relationship depending on the sensitivity of the ecosystem due to differences in species composition, life history traits and biogeochemistry between years (Knapp and Smith, 2001; McCulley et al., 2005; Paruelo et al., 1999).

For a Mediterranean grassland in Portugal, Jongen et al. (2011), using multi-year comparison with flux-tower data, reported a good correlation of productivity with total annual precipitation, with the timing of precipitation only accounting for minor deviations in productivity. This is in agreement with our results presented here, as the change in precipitation frequency, without changing total precipitation quantity, did not affect net productivity. However, it should be noted that the responses of grassland ecosystems to changing precipitation regimes may also depend on the interval between rainfall events and individual event size (Fang et al., 2005; Fay et al., 2008).

Comparison of our results with previous publications reporting on the effects of precipitation variability on productivity in grasslands is difficult, due to differences in climatic conditions or vegetation type of the ecosystems under study. Considering only studies having manipulations comparable to our experiment, i.e. a change in precipitation frequency without changing total precipitation quantity, results show a range of possible ecosystem responses. For example, for annual plant communities in the Mediterranean region, with the vegetation type showing resemblance to our study site, Miranda et al. (2009) reported no significant changes in productivity with decreasing precipitation frequency, which is in agreement with our results. However, annual precipitation in their study sites is $200-250 \mathrm{~mm}$, whereas long-term annual precipitation for our experimental site is $680 \mathrm{~mm}$.

For a mixed grass prairie, with mean annual precipitation of $580 \mathrm{~mm}$, and a long-term mean ANPP of $300 \mathrm{~g} \mathrm{~m}^{-2}$, both characteristics resembling our study site, Heisler-White et al.(2009) reported a $70 \%$ increase in ANPP with larger, less frequent precipitation events. These results contradict our findings. Possible explanations may be found in differences in vegetation types and phenological patterns, with the prairie dominated by perennial $\mathrm{C} 4$ grasses, and in differences in soil characteristics, with the silt-loam soil texture in their study allowing for a much higher soil water holding capacity, thereby increasing plant available water. Moreover,

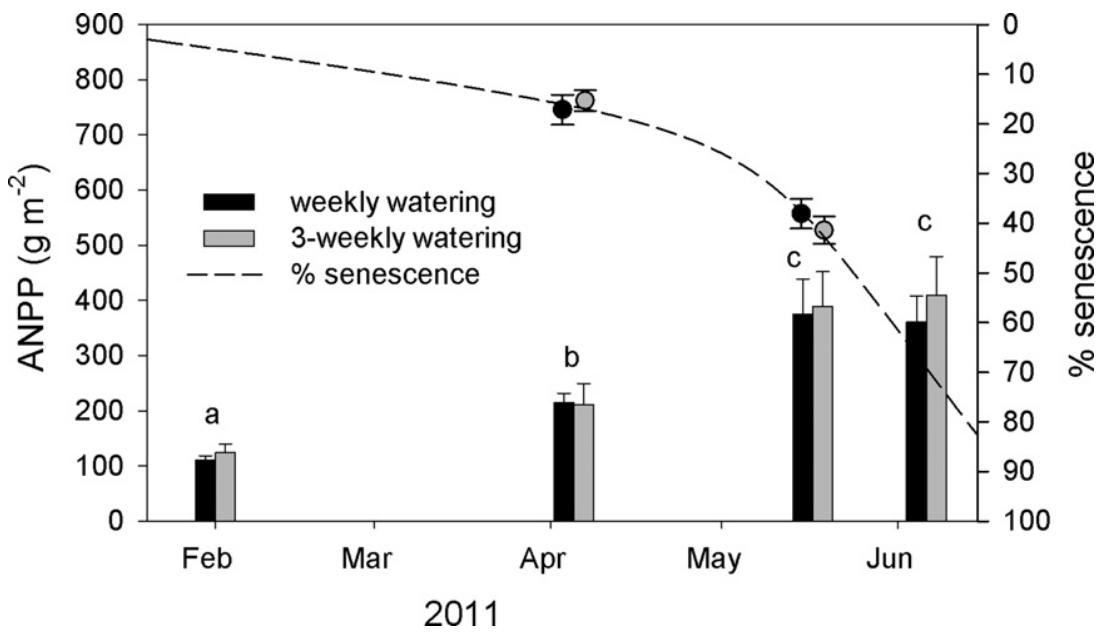

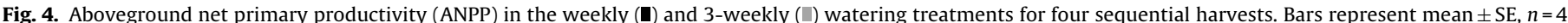

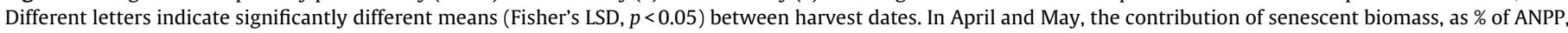

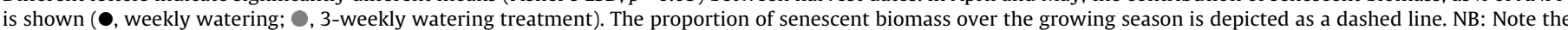
reversed order of the axis of senescent biomass. 


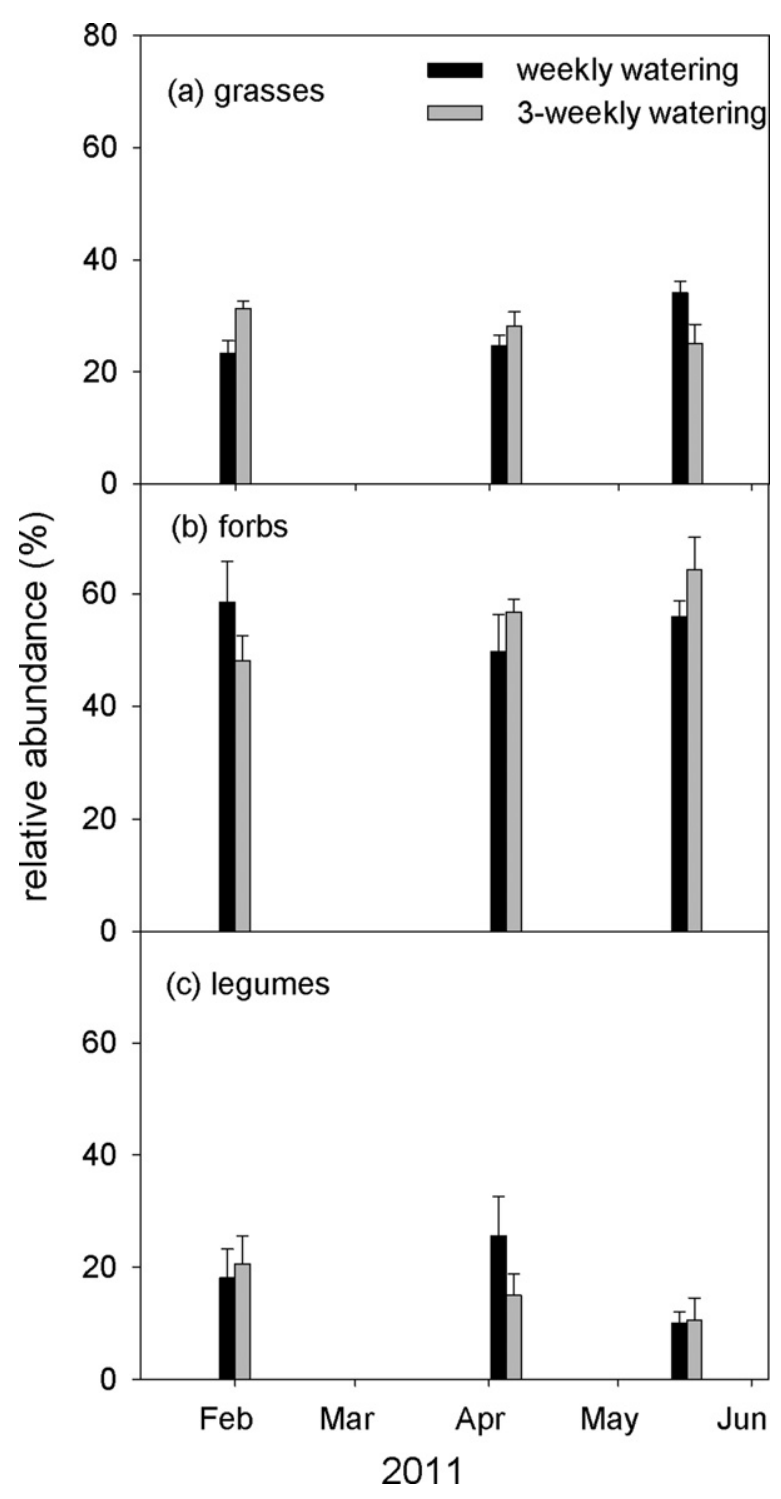

Fig. 5. Relative abundance of (a) grasses, (b) forbs and (c) legumes for three sequential harvests in the weekly (I) and 3-weekly ( $($ ) watering treatments. Data represent percentage biomass contribution to ANPP. Bars show mean $\pm \mathrm{SE}, n=4$.

for two temperate grasslands, Heisler-White et al. (2009) reported opposing productivity responses with changing precipitation patterns, although both ecosystems were structurally similar within the same biome. These results highlight the complexity in predicting the response of an ecosystem to intra-annual precipitation variability.

\subsection{Species composition}

Community structure, expressed as the relative abundance of the functional groups (grasses, forbs and legumes) was not affected by altered precipitation patterns ( $p=0.65$, Fig. 5$)$. The vegetation in this montado understorey is dominated by forbs, accounting on average for $55.5 \pm 2.2 \%$ of ANPP. Prominent species were Rumex acetosella, Tolpis barbata, Bellardia trixago and Spergula arvensis. The latter species, often referred to as a 'winter annual', was the only species with inflorescences in February, accounting for nearly half of all forb biomass at that time. The relative abundance of grasses was $27.8 \pm 1.2 \%$, with Agrostis pourretii and Vulpia geniculata being the prominent species.

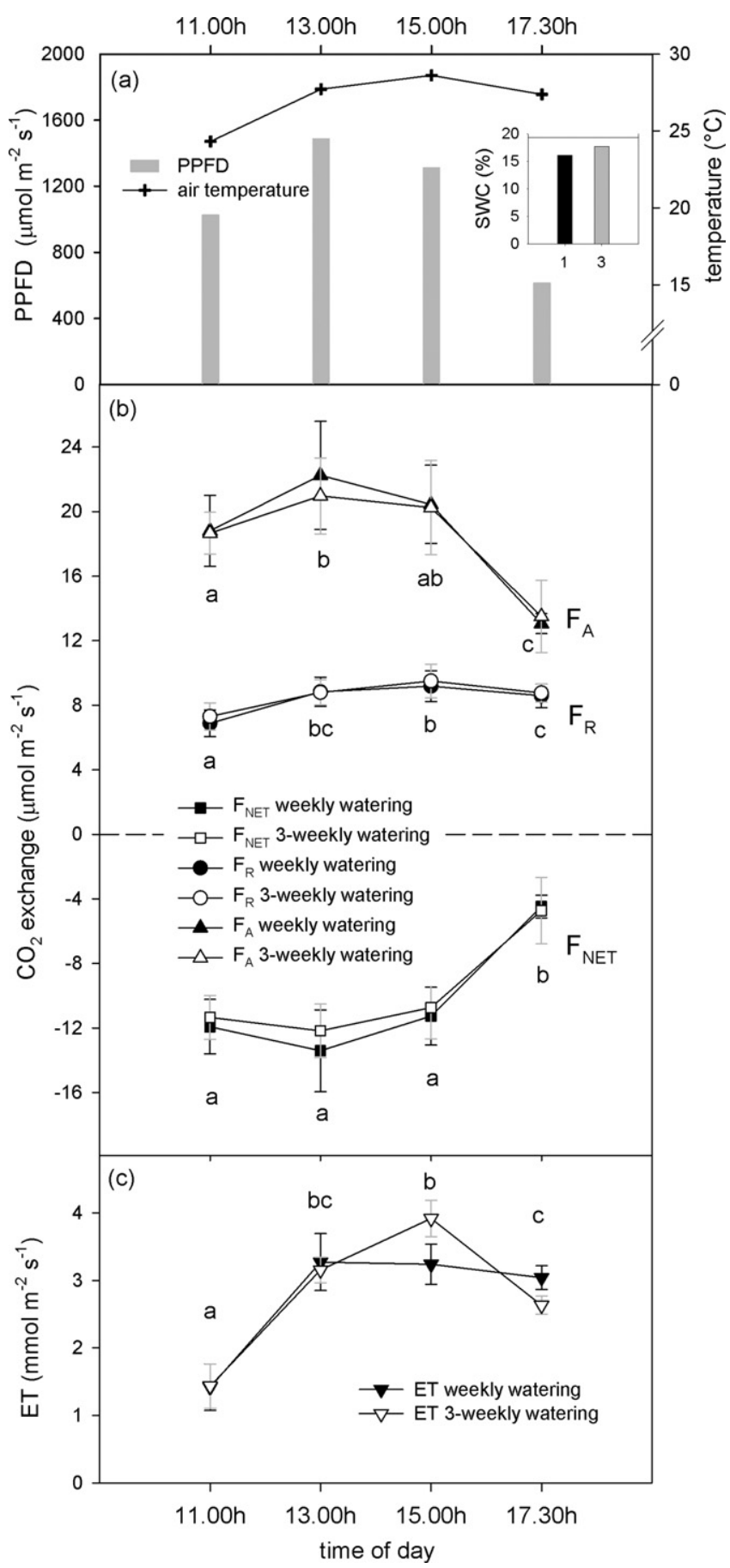

Fig. 6. Diurnal dynamics of vegetation gas exchange on April 1. (a) Air temperature $(-+-)$ and photosynthetic photon flux density (PPFD, - ) at the time of measurements. (b) $\mathrm{CO}_{2}$ exchange dynamics in the weekly (closed symbols) and 3-weekly (open symbols) watering treatments. $F_{\mathrm{NET}}=$ net $\mathrm{CO}_{2}$ exchange $(\boldsymbol{\square}, \square), F_{\mathrm{R}}=\operatorname{respiration}(\bullet, \bigcirc)$ and $F_{\mathrm{A}}=$ assimilation $(\boldsymbol{\Lambda}, \triangle)$. Inset graph shows the soil water content $(\mathrm{SWC})$ in the weekly (घ) and 3-weekly ( $\square$ ) watering treatments at the time of measurements. (c) Evapotranspiration (ET) in the weekly $(\boldsymbol{\nabla})$ and 3-weekly $(\nabla)$ watering treatments. Data represent mean $\pm S E, n=4$. Different letters indicate significantly different means (Fisher's LSD, $p<0.05$ ) at the specific time of day.

Both forbs and grasses showed little change in their relative abundance through the growing season. However, legume contribution to total biomass decreased towards the end of the growing season, with the relative abundance of legumes in February $(19.3 \pm 3.4 \%)$ and April $(20.3 \pm 4.2 \%)$ being higher than in May $(10.3 \pm 2.0 \%)$. Prominent legumes were Ornithopus sativus and 


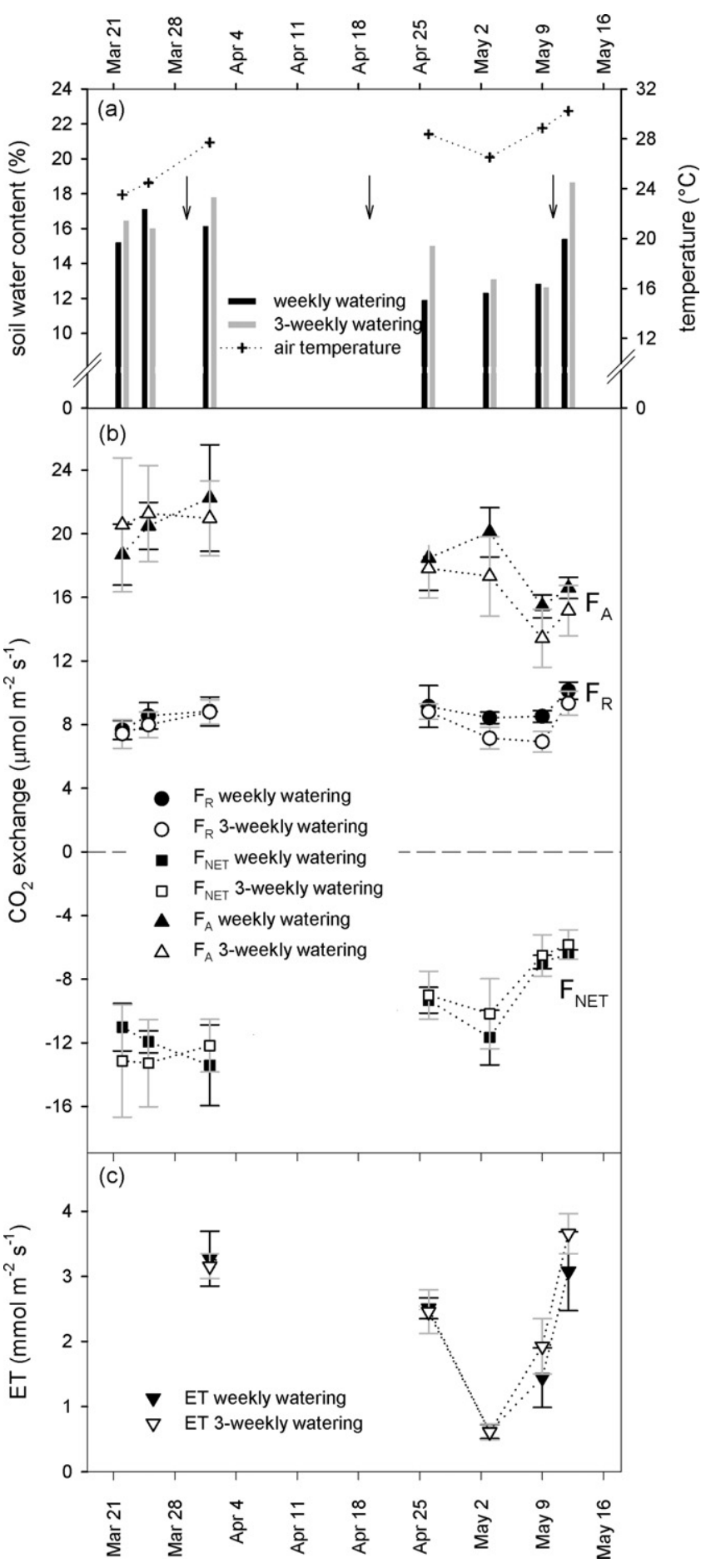

Fig. 7. Springtime dynamics of midday vegetation gas exchange. (a) Air temperature $(+)$ and soil water content in the weekly $(\mathbb{\square})$ and 3-weekly ( $\square$ ) watering treatments at the measurement dates. Arrows indicate the timing of the 3-weekly watering events. (b) Midday $\mathrm{CO}_{2}$ exchange in the weekly (closed symbols) and 3-weekly (open symbols) watering treatments. $F_{\mathrm{NET}}=$ net $\mathrm{CO}_{2}$ exchange $(\boldsymbol{\square}, \square), F_{\mathrm{R}}=$ respiration $(\bullet, \bigcirc)$ and $F_{\mathrm{A}}=$ assimilation $(\boldsymbol{\Lambda}, \triangle)$. (c) Midday evapotranspiration (ET) in the weekly $(\boldsymbol{\nabla})$ and 3-weekly $(\nabla)$ watering treatments. Data represent mean $\pm \mathrm{SE}, n=4$.

Trifolium incarnatum. The decrease in legume contribution in May indicates a higher sensitivity, compared with grasses and forbs, to low soil water availability, as April was characterized by a warm spell. This resulted in an accelerated senescence of the legumes present, shortening the phenological cycle of this functional group.

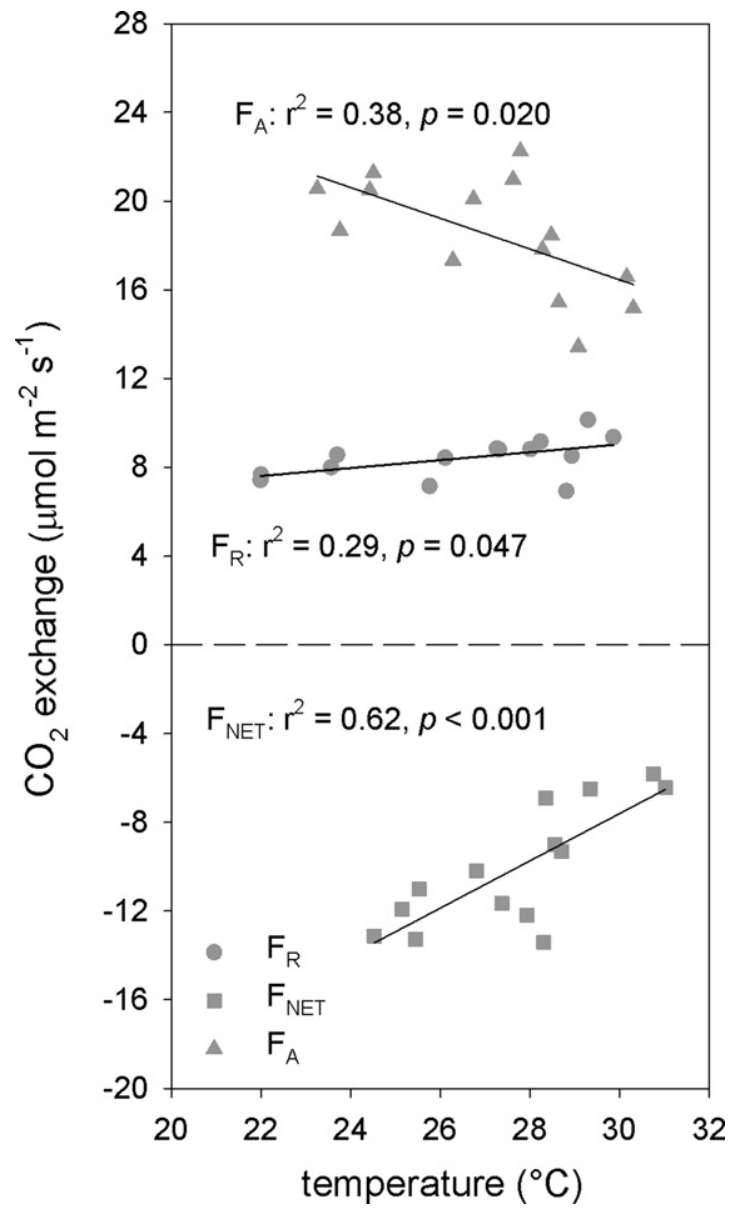

Fig. 8. Correlations between $\mathrm{CO}_{2}$ exchange and air temperature at the time of measurements.

\section{4. $\mathrm{CO}_{2}$ and water vapour fluxes}

An example of the diurnal dynamics of $\mathrm{CO}_{2}$ exchange is presented in Fig. 6b, showing the measurements of April 1. PPFD and air temperature at the measurement times are also shown (Fig. 6a). Under favourable environmental conditions, with SWC > 16\% and daily-integrated PPFD of $38.7 \mathrm{~mol} \mathrm{~m}^{-2}$, the experimental plots showed a high capacity for both C-uptake $\left(F_{\mathrm{A}}\right)$ and respiratory $\mathrm{C}$ loss $\left(F_{\mathrm{R}}\right)$. Maximum values of $F_{\mathrm{NET}}$ and $F_{\mathrm{A}}$ were attained at $13.00 \mathrm{~h}$, with $12.8 \pm 1.2$ and $21.6 \pm 1.7 \mu \mathrm{mol} \mathrm{CO} \mathrm{m}^{-2} \mathrm{~s}^{-1}$, respectively. $F_{\mathrm{R}}$ peaked at $15.00 \mathrm{~h}$, with values of $9.3 \pm 0.6 \mu \mathrm{mol} \mathrm{CO}_{2} \mathrm{~m}^{-2} \mathrm{~s}^{-1}$.

PPFD was strongly correlated with $F_{\mathrm{NET}}$ and $F_{\mathrm{A}}\left(F_{\mathrm{NET}}: r^{2}=0.80\right.$, $\left.p=0.003 ; F_{\mathrm{A}}: r^{2}=0.95, p<0.001\right)$. However, the diurnal dynamics of $F_{\mathrm{R}}$ followed the variation of air temperature $\left(F_{\mathrm{R}}: r^{2}=0.97, p<0.001\right)$. Similarly, the diurnal dynamics of ET (Fig. 6c) were correlated with air temperature $\left(r^{2}=0.94, p<0.0001\right)$, with water vapour fluxes showing peak values of $3-4 \mathrm{mmol} \mathrm{m}^{-2} \mathrm{~s}^{-1}$ in the afternoon.

Alterations in the timing of precipitation had no significant effect on either $\mathrm{CO}_{2}$ exchange $\left(F_{\mathrm{NET}}: p=0.75 ; F_{\mathrm{R}}: p=0.83 ; F_{\mathrm{A}}\right.$ : $p=0.90)$ or ET $(p=0.84)$ of the understorey vegetation, with SWC of 16.1 and $17.7 \%$ in the weekly and 3-weekly watering treatments imposing no limitations on either photosynthetic or respiratory performance.

An overview of seasonal development of vegetation gas exchange (at $13.00 \mathrm{~h}$ ) is presented in Fig. 7. SWC at the measurement dates ranged from 11.9 to $18.6 \%$, with substantial differences between the two watering treatments. For example, SWC in the 3-weekly watering treatment was approx. 3\%-points higher on two of the measurement dates (April 26 and May 12) as compared 
(a) frequent, intermediate precipitation events

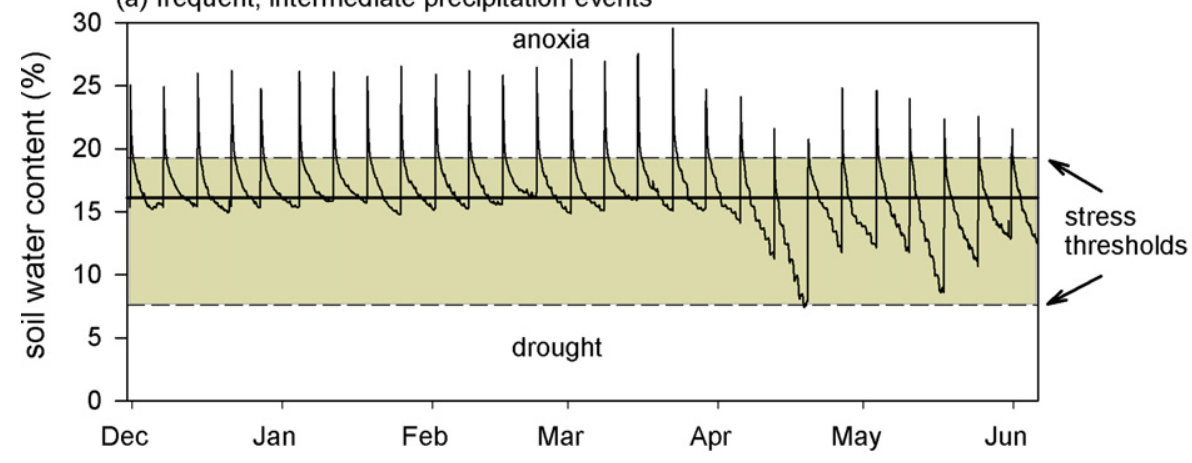

(b) less frequent, large precipitation events

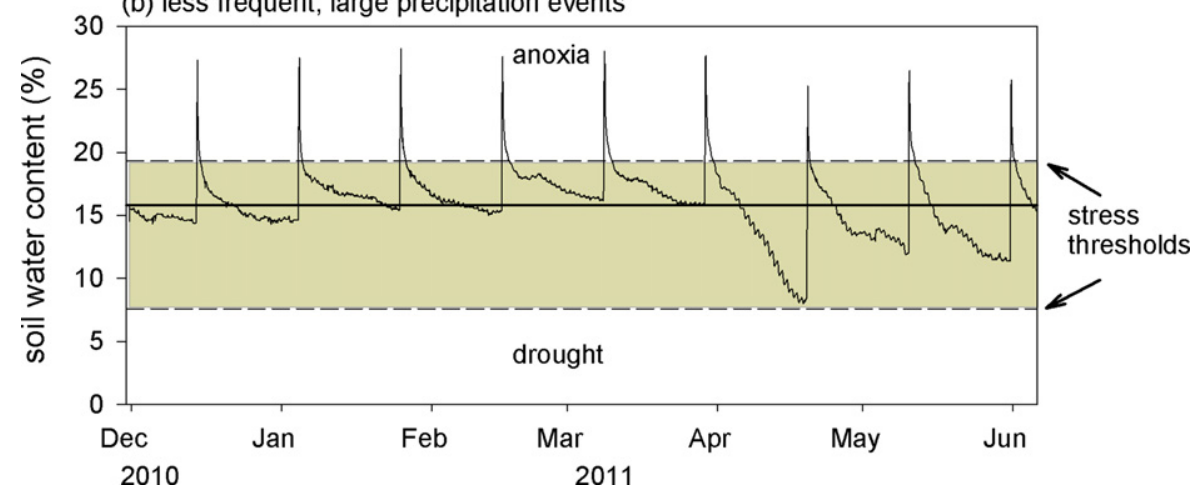

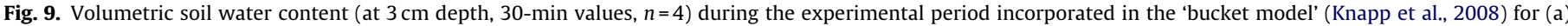

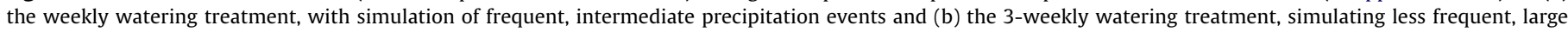

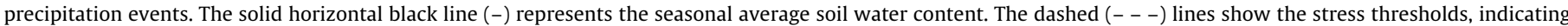

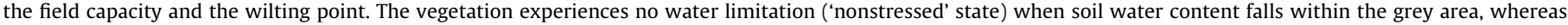
water-limited conditions ('stressed' state) occur when values of soil water content are below the lower stress threshold boundary (wilting point)

to SWC in the weekly watering treatment (Fig. 7a). Nevertheless, $F_{\mathrm{NET}}, F_{\mathrm{R}}$ and $F_{\mathrm{A}}$ were not significantly affected by the watering treatment $\left(F_{\mathrm{NET}}: p=0.96 ; F_{\mathrm{R}}: p=0.39 ; F_{\mathrm{A}}: p=0.75\right.$, Fig. $\left.7 \mathrm{~b}\right)$, indicating that favourable soil moisture conditions existed throughout the growing season. Indeed, SWC did not correlate with $F_{\mathrm{NET}}, F_{\mathrm{R}}$ or $F_{\mathrm{A}}$ (results not shown).

As measurements were only done on clear sky days, PPFD was similar on all dates, with values during measurements of $1430 \pm 28 \mu \mathrm{mol} \mathrm{m}^{-2} \mathrm{~s}^{-1}$. Averaged over the two treatments, midday $F_{\mathrm{NET}}$ ranged from $-12.8 \mu \mathrm{mol} \mathrm{m}^{-2} \mathrm{~s}^{-1}$ (April 1) to $-6.1 \mu \mathrm{mol} \mathrm{m}^{-2} \mathrm{~s}^{-1}$ (May 12), $F_{\mathrm{R}}$ varied from $7.5 \mu \mathrm{mol} \mathrm{m}^{-2} \mathrm{~s}^{-1}$ (March 22) to $9.7 \mu \mathrm{mol} \mathrm{m}^{-2} \mathrm{~s}^{-1}$ (May 12), and values of $F_{\mathrm{A}}$ ranged from $14.4 \mu \mathrm{mol} \mathrm{m}^{-2} \mathrm{~s}^{-1}$ (May 9) to $21.6 \mu \mathrm{mol} \mathrm{m}^{-2} \mathrm{~s}^{-1}$ (April 1). As the growing season progressed, we observed a significant increase in $F_{\mathrm{R}}(p<0.001)$ and a significant decrease in $F_{\mathrm{NET}}(p<0.001)$ and $F_{\mathrm{A}}(p<0.001)$, likely caused by seasonal changes in temperature, leaf area index and senescence of plant material. A good correlation was found between air temperature and the $\mathrm{CO}_{2}$ exchange parameters (Fig. 8). $F_{\mathrm{R}}$ correlated positively with temperature $\left(r^{2}=0.29, p=0.047\right)$, indicating increasing respiratory C-losses at higher temperatures. However, both $F_{\mathrm{NET}}$ and $F_{\mathrm{A}}$ were negatively correlated with air temperature $\left(F_{\mathrm{NET}}: r^{2}=0.62, p<0.001 ; F_{\mathrm{A}}\right.$ : $r^{2}=0.38, p=0.20$ ), indicating a high-temperature dependent reduction of carbon assimilation.

Midday measurements of ET ranged between $0.61 \mathrm{mmol} \mathrm{m}^{-2} \mathrm{~s}^{-1}$ on May 3 and $3.37 \mathrm{mmol} \mathrm{m}^{-2} \mathrm{~s}^{-1}$ on May 12 , with no significant difference between the watering treatments ( $p=0.84$, Fig. 7c). Similar to the $\mathrm{CO}_{2}$ exchange parameters, ET showed a good correlation with air temperature $\left(r^{2}=0.46\right.$, $p=0.029)$. However, in contrast to the $\mathrm{CO}_{2}$ exchange parameters, ET did correlate well with SWC $\left(r^{2}=0.62, p=0.0071\right)$, i.e. the loss of water from the ecosystem was dependent on SWC, with lower values on May 2 and 9, while $\mathrm{CO}_{2}$ assimilation by plants was maintained. Further, the presence of a good correlation between SWC and ET, with no effect on carbon uptake, suggests that the plants were able to optimize carbon assimilation in relation to water supply by increasing intrinsic water use efficiency during the dry periods (Chaves, 1991; Cornic, 2000; Cornic and Massacci, 1996).

The lack in responsiveness of vegetation $\mathrm{CO}_{2}$ exchange to increased precipitation variability may be explained by the understorey species having a high degree of adaptability to smaller scale soil moisture variability. During the growing season, the plants have the ability to cope with irregularities of the precipitation patterns through a high degree of phenotypic plasticity (e.g. Jump and Peñuelas, 2005) and the possibility to employ strategies that improve water uptake and reduce water consumption (Moreno et al., 2008). For example, water deficit can trigger osmotic adjustment (Chaves et al., 2003), permitting the maintenance of leaf turgor through the production of a variety of solutes and enabling additional water extraction from the soil when conditions of water stress develop (Bell et al., 2007).

\subsection{Incorporation of data in the Knapp model}

An additional explanation for the lack of a treatment effect in our study can be found from incorporation of our results of SWC in the 'bucket model' (Fig. 9), originally developed by Knapp et al. (2008). The larger but fewer precipitation events amplify the soil water fluctuations, as predicted by the 'bucket model'. However, manipulation of precipitation variability, extending the dry period from one to three weeks during the growing season, did not result in soil water levels beyond the stress threshold for vegetation productivity (Fig. 9). In mid-April, high temperatures, in combination 
with increasing biomass caused lower water availability for a short period, in both the weekly and 3-weekly watering treatment, with SWC falling to the wilting point. This marks the onset of accelerated leaf senescence. In May, although the soil water decreased rapidly after each irrigation event, the vegetation did not experience water stress as the increased senescence reduced the water demand, thereby avoiding water deficit during seed production and allowing the allocation of scarce resources to the reproductive sinks. In the context of our study, it is important to note that the time of onset of senescence of the annual plant community in the montado understorey did not differ between the two irrigation treatments.

Based on changes in soil water availability with increasing precipitation variability, the 'bucket model' (Knapp et al., 2008) predicts an increase in plant water stress in mesic ecosystems, with concomitant decrease in ANPP, as subsequently reported in several studies (e.g. Fay et al., 2008; Heisler-White et al., 2009). In xeric ecosystems, the 'bucket model' predicts a decrease in water stress, experimentally confirmed by Thomey et al. (2011). However, the effects of increasing precipitation variability on a semi-arid grassland ecosystem, dominated by annual plant species, cannot be predicted by either of the two scenarios presented by Knapp et al. (2008). Based on our results, we propose an additional scenario for the 'bucket model' for semi-arid ecosystems, in which increased precipitation variability does not lead to an increase in plant water stress, as soil moisture does not breach stress thresholds.

\section{Conclusions}

Future climate change scenarios for the Iberian Peninsula predict an increased temporal variability in precipitation regimes (Luterbacher et al., 2006), with a higher frequency of extreme rainfall events, a lower frequency of rainfall days and longer dry periods. For Portugal, recent studies already report intensifying precipitation events, with a concomitant increase in the dry period (Gallego et al., 2011). Our results showed that manipulation of the withinseason precipitation variability, with a three-fold increase of the dry period, without altering total annual precipitation inputs, did not cause significant changes in the productivity, species composition and vegetation gas exchange of the herbaceous component in a typical Mediterranean oak woodland in central Portugal. The understorey vegetation in this ecosystem is dominated by annual plant species, similar to the vegetation in Mediterranean grasslands. Plants germinate in autumn (October) after the first substantial precipitation events, flower and set seed during the spring (April-May) and senesce in June. These plants are adapted to the seasonal severity of the Mediterranean climate, escaping the severe and long summer drought by adjusting their phenological phase (e.g. dormant period in the form of seeds).

The lack of significant differences in the studied ecosystem processes with increasing precipitation variability can be explained by the apparent lack of severity in drought stress caused by changing precipitation patterns, with soil water content during the growing season being above the wilting point in both weekly and 3-weekly watering treatments. This shows that Mediterranean understorey vegetation is capable of coping with a moderate increase in the length of the dry periods during the growing season, while getting larger amounts of water during single rain events, a possible scenario of future climate change. The larger rain events resulted in deeper soil infiltration, which might be beneficial for the deeprooted tree component in this ecosystem (e.g. Q. suber).

Increasing precipitation variability with extensive ( $>3$ weeks) dry periods during the growing season might challenge the phenotypic and physiological plasticity of understorey species with potentially severe consequences for productivity and carbon sequestration of these Mediterranean ecosystems. For this reason, future studies should investigate the extent of adaptability of Mediterranean species to changing environmental conditions with ongoing climate change.

\section{Acknowledgements}

The authors acknowledge the financial support of FCT (Fundação para a Ciência e Tecnologia), through the project PTDC/CLI/64480/2006 and through a postdoctoral fellowship to Marjan Jongen (SFRH/BPD/26914/2006). The authors wish to thank António Gonçalves Ferreira for providing the field site at Machoqueira do Grou, the staff of Machoqueira do Grou, especially Mr. Pirra, for continuous support to the work, Filipe Costa e Silva, Joaquim Mendes, Francesco Minunno and Alexandra Correia for assisting with the construction of the rain-out shelters, Prof. Fernando Monteiro for the measurements of wilting point, Elsa Breia for valuable support in the laboratory, and Peter Fay for suggestions on the manuscript.

\section{References}

Aires, L.M.I., Pio, C.A., Pereira, J.S., 2008. Carbon dioxide exchange above a Mediterranean $\mathrm{C} 3 / \mathrm{C} 4$ grassland during two climatologically contrasting years. Global Change Biol. 14, 539-555.

Bell, L.W., Williams, A.H., Ryan, M.H., Ewing, M.A., 2007. Water relations and adaptations to increasing water deficit in three perennial legumes, Medicago sativa, Dorycnium hirsutum and Dorycnium rectum. Plant Soil 290, 231-243.

Bugalho, M.N., Caldeira, M.C., Pereira, J.S., Aronson, J., Pausas, J.G., 2011. Mediterranean cork oak savannas require human use to sustain biodiversity and ecosystem services. Front. Ecol. Environ. 9 (5), 278-286.

Castro, C., Freitas, H., 2009. Above-ground biomass and productivity in the Montado: from herbaceous to shrub dominated communities. J. Arid Environ. 73, 506-511.

Chaves, M.M., 1991. Effects of water deficits on carbon assimilation. J. Exp. Bot. 42 $1-16$.

Chaves, M.M., Pereira, J.S., Maroco, J., 2003. Understanding plant response to drought - from genes to the whole plant. Funct. Plant Biol. 30, 239-264.

Cornic, G., 2000. Drought stress inhibits photosynthesis by decreasing stomatal aperture - not by affecting ATP synthesis. Trends Plant Sci. 5, 187-188.

Cornic, G., Massacci, A., 1996. Leaf photosynthesis under drought stress. In: Baker N.R. (Ed.), Photosynthesis and the Environment. Kluwer Academic Publishers, Dordrecht, the Netherlands, pp. 347-366.

Cox, P.M., Betts, R.A., Jones, C.D., Spall, S.A., Totterdell, I.J., 2000. Acceleration of global warming due to carbon-cycle feedbacks in a coupled climate model. Nature 408 , 184-187.

Crespo, D., 2010. Species diversity: David Crespo takes C3 pastures the next step to boost soil carbon. Aust. Farm J. 20, 44-47.

Cubera, E., Moreno, G., 2007. Effect of single Ouercus ilex trees upon spatial and seasonal changes in soil water content in dehesas of central western Spain. Ann. Forest Sci. 64 (3), 355-364.

de Lima, M.I.P., Schertzer, D., Lovejoy, S., de Lima, J.L.M.P., 2002. Multifractals and the study of extreme precipitation events: a case study from semi-arid and humid regions in Portugal. In: Singh, V.P., Al-Rashid, M., Sherif, M.M. (Eds.), Surface Water Hydrology. A.A. Balkema Publishers, Lisse, the Netherlands, pp. 195-211.

Easterling, D.R., Evans, J.L., Groisman, P.Y., Karl, T.R., Kunkel, K.E., Ambenje, P., 2000. Observed variability and trends in extreme climate events: a brief review. Bull. Am. Meteorol. Soc. 81, 417-442.

Fang, J., Piao, S., Zhou, L., He, J., Wei, F., Myneni, R.B., Tucker, C.J., Tan, K., 2005 Precipitation patterns alter growth of temperate vegetation. Geophys. Res. Lett. 32, L21411.

Fay, P.A., Carlisle, J.D., Knapp, A.K., Blair, J.M., Collins, S.L., 2003. Productivity responses to altered rainfall patterns in a C4-dominated grassland. Oecologia 137, 245-251.

Fay, P.A., Kaufman, D.M., Nippert, J.B., Carlisle, J.D., Harper, C.W., 2008. Changes in grassland ecosystem function due to extreme rainfall events: implications for responses to climate change. Global Change Biol. 14, 1600-1608.

Figueroa, M.E., Davy, A.J., 1991. Response of Mediterranean grassland species to changing rainfall. J. Ecol. 79, 925-941.

Gallego, M.C., Trigo, R.M., Vaquero, J.M., Brunet, M., García, J.A., Sigró, J., Valente, M.A., 2011. Trends in frequency indices of daily precipitation over the Iberian Peninsula during the last century. J. Geophys. Res. 116, 18, D02109.

Goudriaan, J., van Laar, H.H., 1994. Modelling Potential Crop Growth Processes. Kluwer Academic Publishers, Dordrecht, the Netherlands, 238pp.

Harper, C.W., Blair, J.M., Fay, P.A., Knapp, A.K., Carlisle, J.D., 2005. Increased rainfall variability and reduced rainfall amount decreases soil $\mathrm{CO}_{2}$ flux in a grassland ecosystem. Global Change Biol. 11, 322-334.

Heisler-White, J.L., Blair, J.M., Kelly, E.F., Harmoney, K., Knapp, A.K., 2009. Contingent productivity responses to more extreme rainfall regimes across a grassland biome. Global Change Biol. 15, 2894-2904. 
IPCC, 2007. Climate change 2007: synthesis report. In: Core Writing Team, Pachauri, R.K., Reisinger, A. (Eds.), Contribution of Working Groups I, II and III to the Fourth Assessment Report of the Intergovernmental Panel on Climate Change. IPCC, Geneva, Switzerland, 104pp.

Joffre, R., Rambal, S., Ratte, J.P., 1999. The dehesa system of southern Spain and Portugal as a natural ecosystem mimic. Agroforest Syst. 45, 57-79.

Jongen, M., Pereira, J.S., Aires, L.M., Pio, C.A., 2011. The effects of drought and timing of precipitation on the inter-annual variation in ecosystem-atmosphere exchange in a Mediterranean grassland. Agr. Forest Meteorol. 151, 595-606.

Jump, A.S., Peñuelas, J., 2005. Running to stand still: adaptation and the response of plants to rapid climate change. Ecol. Lett. 8, 1010-1020.

Knapp, A.K., Beier, C., Briske, D.D., Classen, A.T., Luo, Y., Reichstein, M., Smith, M.D., Smith, S.D., Bell, J.E., Fay, P.A., Heisler, J.L., Leavitt, S.W., Sherry, R.A., Smith, B., Weng, E., 2008. Consequences of more extreme precipitation regimes for terrestrial ecosystems. Bioscience 58, 811-821.

Knapp, A.K., Fay, P.A., Blair, J.M., Collins, S.L., Smith, M.D., Carlisle, J.D., Harper, C.W., Danner, B.T., Lett, M.S., McCarron, J.K., 2002. Rainfall variability, carbon cycling, and plant species diversity in a mesic grassland. Science 298, 2202-2205.

Knapp, A.K., Smith, M.D., 2001. Variations among biomes in temporal dynamics of aboveground primary productivity. Science 291, 481-484.

Li, Y.L., Tenhunen, J., Mirzaei, H., Hussain, M.Z., Siebicke, L., Foken, T., Otieno, D., Schmidt, M., Ribeiro, N., Aires, L., Pio, C., Banza, J., Pereira, J.S., 2008. Assessment and up-scaling of $\mathrm{CO}_{2}$ exchange by patches of the herbaceous vegetation mosaic in a Portuguese cork oak woodland. Agr. Forest Meteorol. 148, 1318-1331.

Luterbacher, J., Xoplaki, E., Casty, C., Wanner, H., Pauling, A., Küttel, M., Rutishauser, T., Brönnimann, S., Fischer, E., Fleitmann, D., Gonzalez-Rouco, F.J., GarcíaHerrera, R., Barriendos, M., Rodrigo, F., Gonzalez-Hidalgo, J.C., Saz, M.A., Gimeno, L., Ribera, P., Brunet, M., Paeth, H., Rimbu, N., Felis, T., Jacobeit, J., Dünkeloh, A., Zorita, E., Guiot, J., Türkes, M., Alcoforado, M.J., Trigo, R., Wheeler, D., Tett, S., Mann, M.E., Touchan, R., Shindell, D.T., Silenzi, S., Montagna, P., Camuffo, D., Mariotti, A., Nanni, T., Brunetti, M., Maugeri, M., Zerefos, C., De Zolt, S., Lionello, P., Nunes, M.F., Rath, V., Beltrami, H., Garnier, E., Ladurie, E.L.R., 2006. Mediterranean climate variability over the last centuries: a review. In: Lionello, P., Malanotte-Rizzoli, P., Boscolo, R. (Eds.), The Mediterranean Climate: An Overview of the Main Characteristics and Issues. Elsevier, Amsterdam, the Netherlands, pp. 27-148.

McCulley, R.L., Burke, I.C., Nelson, J.A., Lauenroth, W.K., Knapp, A.K., Kelly, E.F., 2005. Regional patterns in carbon cycling across the Great Plains of North America. Ecosystems 8, 106-121.

Miranda, J.D., Padilla, F.M., Lázaro, R., Pugnaire, F.I., 2009. Do changes in rainfall patterns affect semiarid annual plant communities? J. Veg. Sci. 20, 269-276.

Miranda, P.M.A., Valente, M.A., Tomé, A.R., Trigo, R., Coelho, F., Aguiar, A., Azevedo, E.B., 2006. O clima de Portugal nos séculos XX e XXI. In: Santos, F.D., Miranda, P. (Eds.), Alterações climáticas em Portugal - Cenários, impactes e medidas de adaptação. Gradiva, Lisboa, pp. 45-113.

Moreno, G., Obrador,J.J., Cubera, E., Dupraz, C., 2005. Fine root distribution in dehesas of Central-Western Spain. Plant Soil 277, 153-162.

Moreno, G., Pulido, F.J., 2008. The functioning management and persistence of dehesas. In: Rigueiro-Rodróguez, A., McAdam, J., Mosquera-Losada, M.R. (Eds.), Agroforestry in Europe. Advances in Agroforestry. Springer, the Netherlands, pp. 127-160.
Moreno, M., Gulías, J., Lazaridou, M., Medrano, H., Cifre, J., 2008. Ecophysiological strategies to overcome water deficit in herbaceous species under Mediterranean conditions. Opt. Médit. 79, 247-256.

Moreno Marcos, G., Obrador, J.J., García, E., Cubera, E., Montero, M.J., Pulido, F. Dupraz, C., 2007. Driving competitive and facilitative interactions in oak dehesas through management practices. Agroforest Syst. 70, 25-40.

Otieno, D.O., Kurz-Besson, C., Liu, J., Schmidt, M.W.T., do Vale-Lobo, R., David, T.S., Siegwolf, R., Pereira, J.S., Tenhunen, J.D., 2006. Seasonal variations in soil and plant water status in a Quercus suber L. stand: roots as determinants of tree productivity and survival in the Mediterranean-type ecosystem. Plant Soil 283, 119-135.

Otieno, D.O., Mirzaei, H., Hussain, M.Z., Li, Y.L., Schmidt, M.W.T., Wartinger, M., Jung, E., Ribeiro, N., Pereira, J.S., Tenhunen, J., 2011. Herbaceous layer development during spring does not deplete soil nitrogen in the Portuguese montado. J. Arid Environ. 75, 231-238.

Paredes, D., Trigo, R.M., García-Herrera, R., Trigo, I.F., 2006. Understanding precipitation changes in Iberia in early spring: weather typing and storm-tracking approaches. J. Hydrometeorol. 7, 101-113.

Paruelo, J.M., Lauenroth, W.K., Burke, I.C., Sala, O.E., 1999. Grassland precipitationuse efficiency varies across a resource gradient. Ecosystems 2, 64-68.

Pereira, J.S., Mateus, J.A., Aires, L.M., Pita, G., Pio, C., David, J.S., Andrade, V., Banza, J., David, T.S., Paço, T.A., Rodrigues, A., 2007. Net ecosystem carbon exchange in three contrasting Mediterranean ecosystems - the effect of drought. Biogeosciences 4, 791-802.

Pires, V.C., 2003. Frequência e intensidade de fenómenos meteorológicos extremos associados à precipitação: desenvolvimento de um sistema de monitorização de situações de seca em Portugal continental. University de Lisboa, Lisboa.

R Development Core Team, 2010. R: A Language and Environment for Statistical Computing. R Foundation for Statistical Computing, Vienna, Austria.

Sala, O.E., Parton, W.J., Joyce, L.A., Lauenroth, W.K., 1988. Primary production of the central grassland region of the United States. Ecology 69, 40-45.

Thomey, M.L., Collins, S.L., Vargas, R., Johnson, J.E., Brown, R.F., Natvig, D.O., Friggens, M.T., 2011. Effect of precipitation variability on net primary production and soil respiration in a Chihuahuan Desert grassland. Global Change Biol. 17, 1505-1515.

Trigo, R.M., DaCamara, C.C., 2000. Circulation weather types and their influence on the precipitation regime in Portugal. Int. J. Climatol. 20, 1559-1581.

Unger, S., Máguas, C., Pereira, J.S., Aires, L.M., David, T.S., Werner, C., 2010. Disentangling drought-induced variation in ecosystem and soil respiration using stable carbon isotopes. Oecologia 163, 1043-1057.

Unger, S., Máguas, C., Pereira, J.S., Aires, L.M., David, T.S., Werner, C., 2009. Partitioning carbon fluxes in a Mediterranean oak forest to disentangle changes in ecosystem sink strength during drought. Agr. Forest Meteorol. 149, 949-961.

Vázquez-de-Aldana, B.R., García-Ciudad, A., García-Criado, B., 2008. Interannual variations of above-ground biomass and nutritional quality of Mediterranean grasslands in Western Spain over a 20-year period. Aust. J. Agr. Res. 59, 767-779.

Yang, Y., Fang, J., Ma, W., Wang, W., 2008. Relationship between variability in aboveground net primary production and precipitation in global grassland. Geophys. Res. Lett. 35 (L23710), 4. 